\title{
The Effects of Lifestyles on Sustainable Consumption: A Conceptual Study of Cosmetics and Personal Care Products
}

\author{
Azlinah Ambak ${ }^{1}$, Irwan Yusof ${ }^{2}$, Sulaiman Yamin ${ }^{3}$ and Suhaimi Mohd Shamsuddin ${ }^{4}$ \\ \{azlinahktb@yahoo.com ${ }^{1}$, irwanyusof@yahoo.com ${ }^{2}$, sulaimanyamin2@gmail.com ${ }^{3}$, \\ suhazlin@yahoo.com $\left.{ }^{4}\right\}$ \\ 1,2,3,4 University College Bestari, Terengganu, Malaysia
}

\begin{abstract}
Nowadays, it is noticeable that marketing strategies are moving towards sustainability due to several unsustainable consumption problems and one of the problems is packaging waste. Central to the problem is lifestyle. Lifestyle is one of the variables which fall within psychographic segmentation. Segmentation is the process where the market is divided into relevant groups that can be targeted by marketers. Previous study has employed VALS and AIO in India to predict lifestyle. Thus this study will also employ both measurement systems to re-validate the study findings in Malaysia and at the same time complement each measurement system deficiencies in defining lifestyles. Therefore, this study aims to identify the effect of consumers' lifestyles of cosmetics and personal care products on sustainable consumption that can allow marketers and researcher to predict their different consumption habits that are reflected by different lifestyles. This conceptual study is solely based on an extensive review from literature and previous data. The sources of collecting literature are Google search and digital library. This study is expected to prove that self-fulfilment, self-identity, feeling of uniqueness and believers segment is the dominant lifestyle that makes more sustainable consumption.
\end{abstract}

Keywords: Sustainable Consumption, Psychographic Segmentation, VALS, AIO, Cosmetics and Personal Care Products

\section{Introduction}

The development of cosmetic industry has been growing globally in both developed and developing countries (Azmi Hassali and AL-Tamimi, 2015). According to (Khan et al., 2017), cosmetic industry growth is shifted from Western region to developing hemisphere of Asia. Meanwhile Malaysia's total trade volume for personal care and cosmetics products had increased about US\$2.24 billion in 2015 (Cheong et al., 2016). This continuous growth and evolution in cosmetics industry offers great consumption and thus wastes. Moreover Malaysians had generated about 30, 000 metric tonnes of rubbish each day (Jereme et al., 2015). As a result, solid waste and solid waste management have given rise to many pressing issues in Malaysia and product packaging is a big contributor to the landfills in a near future (MHLG, 2006).

There are several problems emerged due to unsustainable consumption such as solid waste which is already a significant problem for Malaysia government (Haron, Paim and Yahaya, 2005). These consumption problems occurred due to the socio economic structure, industrial development, an urbanization process, increase population and individual actors' options and choices and a changing lifestyle (Briceno and Stagl, 2006); (Haron, Paim and Yahaya, 2005). Therefore this study will discuss about problem emanated from consumers' lifestyles through these consumption habits. Moreover understanding what determines 
consumer behaviour provides a useful starting point for identifying the lifestyles of Malaysian consumption behaviour. Therefore making recommendations as to develop conceptual framework for sustainable consumption might help marketers or researchers to enrich the field of sustainable consumption research that is relatively new (Reisch et al., 2016).

This study aims to identify the effect of consumers' lifestyles of cosmetics and personal care products on sustainable consumption that can allow marketers and researchers to predict their different consumption habits that are reflected by different lifestyles. Hence, these lifestyles that fall under psychographic segmentation might help the marketers to tap Malaysian market and to empower the sustainable marketing. There are two questions that have been developed which are (1) How consumers' lifestyles of cosmetics and personal care products give an impact to sustainable consumption? and (2) Which consumers' lifestyles of cosmetics and personal care products make more impacts on sustainable consumption?

\subsection{Packaging Waste}

(Vranjanac and Spasic, 2017) cited that packaging waste from personal care and cleaning products such as plastics bags and bottles caps, cardboard and plastic boxes should not be scattered around the environment but deposited at predetermined locations in compliance with local or national legislation. When cosmetics and personal care products are used up, tons of wastes are generated from the package that ends up in landfills (Girotto G., 2012); (Vranjanac and Spasic, 2017). According to Malaysian environment and waste management specialist, Dr Theng Lee Chong said that solid waste generation had created a major problems which are lack of landfill space, low recycling rate (Noor, 2016), pollution (Samah et al., 2013) and littering. Hence these problems should be solved from the source. Waste initially requires certain economic means to be managed properly, including the costs of collection, transport, storage and treatment (Vranjanac and Spasic, 2017). Composition of solid waste from personal care products and cleaning products had been determined in a study by Pejcic and Vranjana (2016) that was cited in (Vranjanac and Spasic, 2017). The study was done in Serbia, and the result showed that plastic packaging had the biggest mass percentage of the four categories (46\%). It was followed by glass packaging (34\%), aluminium packaging $(12 \%)$, and paper and cardboard packaging $(8 \%)$ of the total packaging waste mass.

Due to the lack of data collection on packaging waste composition in Malaysia, the actual figures for packaging waste composition in Malaysia are not available. But the study that was done by (Periathamby, Hamid and Khidzir, 2009) had categorized the solid waste composition in Malaysia from 1975 to 2005 according to organic, paper, plastic, glass, metal, textiles, wood and others, and it was categorized more clearly by National Solid Waste Management Department (NSWMD), Ministry of Housing and Local Government Malaysia (National Solid Waste Management Department, 2011). NSWMD categorized the types of solid waste composition in 2005 according to organic waste contributed approximately $45 \%$, followed by plastic $(24 \%)$, paper waste $(7 \%)$, metal $(6 \%)$, glass $(3 \%)$ and others $(15 \%)$.

According to (National Solid Waste Management Department, 2011), the category of plastic that are used to produce personal care products fall under easy plastics to recycle, meanwhile the type of plastic resins and their respective symbol codes and classification fall under number 2 which reserved for high density polyethylene plastics (HDPE). The most used polymer United Kingdom (UK) is HDPE which is $20 \%$ of total consumer (household) plastic packaging. The majority of HDPE plastic packaging is bottles (54\%) and it is mainly used to package milk and personal care products, due to its chemical resistant properties (WRAP, 2013). But somehow the product packaging might be hazardous when these formulating with the substances that would react with others, produce additional compounds that when attaining 
with certain additional concentration levels might be capable of causing severe environmental and public health damage (Adamcová et al., 2016).

\subsection{The Importance Of Psychographic Segmentation}

The task of the marketers is to identify the appropriate number and nature of market segments and decide which (one)s to target. According to (Kumar et al., 2012), marketing strategy comprises of segmentation, targeting and positioning and marketing mix of the company. The first process in marketing strategy is segmentation that divides a market into a smaller group of buyers with distinctive needs, characteristics or behaviours who might require marketing mix separately (Kotler and Armstrong, 2008). Market segmentation is an essential element of marketing as we want to develop the most profitable segment by giving them what they need, want and how to communicate with them accordingly (Cahill, 1997). Without segmentation, it is difficult for marketers to do market targeting strategy precisely. With respect to that, it is impossible to create a marketing mix which is solid and costeffective.

Psychographics variable is one of the market segmentation which scientifically uses psychology and demographics to understand the consumers. In psychographic segmentation, a market is divided into different groups of psychological/personality traits, lifestyle or values (Kotler and Armstrong, 2008). Generally, most of the definition of lifestyle is the way we live our lives, but it is not that easy to define a lifestyle (Jensen, 2007). This statement is also supported by (Ryden et al., no date). According to (Nora, Liza \& Minarti, 2016), lifestyle is about what they do, what do they buy and how they spend their time. Meanwhile (Sjöberg and Engelberg, 2005) defines lifestyles to three different meanings:

- The value shown by referring to a limited number of basic dimensions (freedom, justice, equality, etc.).

- Groups or groups of attitudes, opinions, interests and activities.

- The real behavior pattern. According to (Ryden et al., no date), lifestyles come from a series of special and occasional behaviors forming a pattern that can be called a lifestyle.

In this study the definition of lifestyle will be discussed in three different meanings which are values, groups of attitudes, opinions, interests and activities and consumption patterns.

The marketers need to utilize the precise information from subgroups of psychographic segmentation to develop their commercial direction (Abduljalil and Tat, 2011) and to predict their behaviour; particularly in consumer behaviour that reflects consumer values that best show their lifestyle (Aydın and Ünal, 2015). Thus, different life styles will result in different consumption habits. In this case lifestyles must be measured appropriately plus with cultural differentiation. Measurement systems that are commonly employed to measure the first meaning of lifestyles which is values and consumption patterns which are The List of Values (LOV), Values and Lifestyles (VALS) (Abduljalil and Tat, 2011); (Aydın and Ünal, 2015); (Ghosh, 2014); and the Rokeach Value Survey (Vinson, Munson and Nakanishi, 1977). Meanwhile Activities, Interest and Opinions (AIO) (Narang, 2011) is used to measure another meaning of lifestyles which is groups of attitudes, interests, opinions and activities. Each of measurement systems has its strengths and limitations as according to Table 1. 
Table 1. Strengths and Limitations of Measurement Systems in Lifestyles

\begin{tabular}{|c|c|c|}
\hline $\begin{array}{l}\text { Measurement } \\
\text { Systems }\end{array}$ & Strengths & Limitations \\
\hline $\begin{array}{l}\text { Values } \quad \& \\
\text { Lifestyles } \\
\text { (VALS) }\end{array}$ & $\begin{array}{l}\text { - It comprises demographics, } \\
\text { attitudes, activities, consumption } \\
\text { patterns, brand preferences \& media } \\
\text { graphics (Sathish and Rajamohan, } \\
\text { 2012). } \\
\text { - It can stand alone without including } \\
\text { extra demographic variables (Novak } \\
\text { and MacEvoy, 1990). }\end{array}$ & $\begin{array}{l}\text { - It is a general framework to } \\
\text { understand (Winters, 1989). } \\
\text { - It is very weak at predicting } \\
\text { people's purchase \& too } \\
\text { culturally specific for } \\
\text { international use (Yankelovich } \\
\text { and Meer, 2006). }\end{array}$ \\
\hline $\begin{array}{l}\text { ROKEACH } \\
\text { Value Survey } \\
\text { (RVS) }\end{array}$ & $\begin{array}{l}\text { - It is a values hierarchy that enables } \\
\text { researchers to describe } \\
\text { quantitatively (Vinson, Munson and } \\
\text { Nakanishi, 1977). }\end{array}$ & $\begin{array}{l}\text { - It is positive response bias in } \\
\text { cross cultural comparison } \\
\text { (Jabes, no date). }\end{array}$ \\
\hline $\begin{array}{l}\text { Attitudes, } \\
\text { Interest \& } \\
\text { Opinion (AIO) } \\
\end{array}$ & $\begin{array}{l}\text { - It is self-administered (González } \\
\text { and Bello, 2002). }\end{array}$ & $\begin{array}{l}\text { - Lengthy (a wide range of } \\
\text { features) (González and Bello, } \\
\text { 2002). }\end{array}$ \\
\hline $\begin{array}{l}\text { List of Values } \\
\text { (LOV) }\end{array}$ & $\begin{array}{l}\text { - It is easy to understand the cultural } \\
\text { aspects based on social values } \\
\text { (Begunca, 2017); . } \\
\text { - It obtains demographic predictions } \\
\text { separately \& simple to administer } \\
\text { (Lynn R. Kahle, Sharon E. Beatty, } \\
\text { 1988). }\end{array}$ & $\begin{array}{l}\text { - It is less predictive when there } \\
\text { is no extra demographic } \\
\text { variable (Novak and MacEvoy, } \\
\text { 1990). }\end{array}$ \\
\hline
\end{tabular}

\subsection{Sustainable Consumption}

The concept of sustainable consumption that was coined in Oslo in 1994 was in line with the Brundtland commission definition of sustainable development. The definition of sustainable production and consumption is "the use of goods and services that respond to basic needs and bring a better quality of life, while protecting the environment, so as not to jeopardize the needs of future generations" (Nations, Programme and Unep, 2010). Meanwhile (Maria Geiger et al., 2017) defined sustainable consumption behaviour (SCB) as "individual acts of satisfying needs in different areas of life by acquiring, using and disposing goods and services that do not compromise the ecological and socioeconomic conditions of all people (currently living or in the future) to satisfy their own needs".

Therefore in this study, sustainable consumption is defined as a process that focuses on acquiring and disposing the cosmetics and personal care products while protecting environment. This study will employ SBC cube that is proposed by (Fischer et al., 2017) to define sustainable consumption whereby the sustainability dimension is ecological, the consumption phase is acquiring and disposing and the consumption area is cosmetics and personal care products. Meanwhile the impact assessment approaches reported by (Fischer et al., 2017), have a strong tradition with ecological realm.

There are several studies that are dealing with both consumers' lifestyles and sustainable consumption such as studies from (Fraj and Martinez, 2006); (Adnan, Ahmad and Khan, 2017); (Aydın and Ünal, 2015) as shown in table 2. 
Table 2. Findings from Previous Studies Dealing With Consumers' Lifestyles And Sustainable Consumption

\begin{tabular}{|c|c|c|}
\hline $\begin{array}{l}\text { Authors / } \\
\text { Country }\end{array}$ & $\begin{array}{l}\text { Measureme } \\
\text { nt systems }\end{array}$ & Findings \\
\hline $\begin{array}{l}\text { Fraj and Martinez } \\
(2006) \text { / Spain }\end{array}$ & VALS & $\begin{array}{l}\text { Ecological segment is best characterised with self- } \\
\text { fulfilment feeling. They have ecological lifestyle } \\
\text { (environment consciousness, selecting and recycling } \\
\text { products and taking part in events to protect environment). }\end{array}$ \\
\hline $\begin{array}{l}\text { Adnan, Ahmad } \\
\text { and Khan (2017) } \\
\text { / India }\end{array}$ & $\begin{array}{l}\text { VALS } \\
\text { AIO }\end{array}$ & $\begin{array}{l}\text { Ecological segment is best characterised with self-identity } \\
\text { and feeling of uniqueness. They have ecological lifestyle } \\
\text { (selecting and recycling products and taking part in events } \\
\text { to protect environment). }\end{array}$ \\
\hline $\begin{array}{l}\text { Aydin and Unal } \\
(2015) \text { / Turkey }\end{array}$ & VALS & $\begin{array}{l}\text { Consumers' lifestyles have an impact on their sustainable } \\
\text { consumption trends. Innovators and thinkers carry more } \\
\text { information about environmental problems and have more } \\
\text { positive attitude. Meanwhile thinkers and believers make } \\
\text { more sustainable consumption. }\end{array}$ \\
\hline
\end{tabular}

\section{Problem Statements}

VALS and AIO are both measurement systems that will be employed in this study since the definition of lifestyles consists of three different meanings which are values, groups of attitudes, interests, opinions and activities and consumption patterns. This study employs both of the measurement systems to complement each measurement system in defining lifestyles. According to one of the strengths of VALS, it shows that VALS can measure almost every meaning of lifestyles. Meanwhile the employment of AIO might give results which measurement is much stronger in predicting lifestyles between VALS and AIO in terms of activities, interests and opinions. Meanwhile previous study was done by (Adnan, Ahmad and Khan, 2017) in India. Hence this study will be done in Malaysia that might help to re-validate the study findings in other cultural differentiation.

\section{Research Methodology}

This conceptual study is solely based on a review from literature and data. The sources of collecting literature are Google search and digital library. The terms such as sustainable consumption, VALS, cosmetics and personal care products and solid waste were used and there was limited amount of information were found. The most helpful pieces of literature were studied by (Aydın and Ünal, 2015), (Fraj and Martinez, 2006) and (Adnan, Ahmad and Khan, 2017).

\section{Conclusion}

From the previous study by (Aydın and Ünal, 2015), the model exploring the influence of lifestyles, environmental knowledge and environmental attitude on sustainable consumption, environmental knowledge and attitude towards environmental protection have an influence on sustainable consumption. They might also have ecological lifestyle (environment consciousness (Fraj and Martinez, 2006), selecting and recycling products and taking part in events to protect environment (Adnan, Ahmad and Khan, 2017)). Meanwhile ecological segment is best characterised with self-fulfilment feeling (Fraj-Andrés and 
Martínez-Salinas, 2007), self-identity and feeling of uniqueness (Adnan, Ahmad and Khan, 2017). Moreover the ecological segment might consists of thinkers who are the most lifestyle that engage in sustainable consumption more compared to the others and followed by believers (Aydın and Ünal, 2015).

Lifestyles are the central to all the consumption habits. Marketers and researchers have to study the consumers' lifestyles of cosmetics and personal care products since the consumption of the products has expanding and growing although in uncertain environment. There might be changing in consumers' lifestyle in the future and changing lifestyle might not agitate the marketers if they have the scale of lifestyles that is able to predict consumers' consumption habits.

Meanwhile the marketers could strategize the market targeting as well as positioning and marketing mix precisely and above all, all the marketing strategies which in line with sustainable consumption especially to protect environment. It is suggested that an extensive study should be done using different lifestyles scale systems.

In the future, the facts and figures of packaging wastes composition should be categorized accordingly to mitigate the waste management and recycling and might also to facilitate the researchers and policymakers in identifying which aspect (any brand or product) has contributed most to the packaging wastes.

\section{References}

[1] Abduljalil, S. and Tat, H. H. (2011) 'The Role of Psycographic for Distinguishing Main Categories of Consumers Based On Lifestyle, Personality and Value Variables', International Journal of Economics and Research, 2(AUGUST), pp. 29-34.

[2] Adamcová, D., Vaverková, M. D., Stejskal, B. and Břoušková, E. (2016) 'Household solid waste composition focusing on hazardous waste', Polish Journal of Environmental Studies, 25(2), pp. 487-493. doi: 10.15244/pjoes/61011.

[3] Adnan, A., Ahmad, A. and Khan, M. N. (2017) 'Examining the role of consumer lifestyles on ecological behavior among young Indian consumers', Young Consumers, 18(4), pp. 348-377. doi: 10.1108/YC-05-2017-00699.

[4] Aydın, H. and Ünal, S. (2015) 'A Study on the Effects of the Consumer Lifestyles on Sustainable Consumption', Inquiry, 1(2), pp. 133-152.

[5] Azmi Hassali, M. and AL-Tamimi, S. K. (2015) 'Malaysian Cosmetic Market: Current and Future Prospects', Pharmaceutical Regulatory Affairs: Open Access, 04(04), pp. 10-13. doi: 10.4172/2167-7689.1000155.

[6] Begunca, A. (2017) 'Identifying Lifestyles of Kosovo Beer Consummers', European Journal of Sustainable Development, 6(1), pp. 123-138. doi: 10.14207/ejsd.2017.v6n1p123.

[7] Briceno, T. and Stagl, S. (2006) 'The role of social processes for sustainable consumption', Journal of Cleaner Production, 14(17), pp. 1541-1551. doi: 10.1016/j.jclepro.2006.01.027.

[8] Cahill, D. J. (1997) 'Target marketing and segmentation: valid and useful tools for marketing', Management Decision, 35(1), pp. 10-13. doi: 10.1108/00251749710160133.

[9] Cheong, S., Coulthart, J., Kanawati, J., Han, A., Li, J., Maryarini, P., Ono, C., Pookan, M., Robles, D., Rumeral, Y., Sherigar, S., Yan, S., Yeoh, T., Theseira, L. and Baik, H. (2016) 'Asia Personal Care Cosmetics Market Guide 2016', Book, p. 234.

[10] Fischer, D., Stanszus, L., Geiger, S., Grossman, P. and Schrader, U. (2017) 
'Mindfulness and sustainable consumption: A systematic literature review of research approaches and findings', Journal of Cleaner Production, 162(July), pp. 544-558. doi: 10.1016/j.jclepro.2017.06.007.

[11] Fraj-Andrés, E. and Martínez-Salinas, E. (2007) 'Impact of Environmental Knowledge on Ecological Consumer Behaviour: An Empirical Analysis.', Journal of International Consumer Marketing, 19(3), pp. 73-102. doi: 10.1300/J046v19n03.

[12] Fraj, E. and Martinez, E. (2006) 'Environmental values and lifestyles as determining factors of ecological consumer behaviour: An empirical analysis', Journal of Consumer Marketing, 23(3), pp. 133-144. doi: 10.1108/07363760610663295.

[13] Ghosh, I. (2014) 'VALS TM Psychographic: A New Way of Market Segmentation in India Abstract':, the International Journal of Business \& Management, 2(4), pp. 25 30 .

[14] Girotto G. (2012) 'Sustainability and Green Strategies in the Cosmetic Industry ':

[15] González, A. M. and Bello, L. (2002) The construct "lifestyle” in market segmentation, European Journal of Marketing. doi: 10.1108/03090560210412700.

[16] Haron, S. A., Paim, L. and Yahaya, N. (2005) 'Towards sustainable consumption: An examination of environmental knowledge among Malaysians', International Journal of Consumer Studies, 29(5), pp. 426-436. doi: 10.1111/j.1470-6431.2005.00460.x.

[17] Jabes, S. A. A. and J. (no date) 'Positive Response Bias in Cross Cultural Comparisons: Case of Rokeach Value Scale', Proceedings of the 1984 Academy of Marketing Science (AMS) Annual Conference, pp. 143-144.

[18] Jensen, M. (2007) 'Defining lifestyle', Environmental Sciences, 4(2), pp. 63-73. doi: 10.1080/15693430701472747.

[19] Jereme, I. A., Siwar, C., Begum, R. A., Talib, B. A. and Alam, M. (2015) 'Assessing Problems and Prospects of Solid Waste Management in Malaysia', 10(2), pp. 70-87.

[20] Khan, I., Dongping, H., Abdullah, M., Ahmad, Z., Ahmad Ghauri, T. and Ghazanfar, S. (2017) 'Men's attitude and motivation toward consumption of grooming products: A comparison of Chinese and Pakistani male consumers', Cogent Business and Management. Cogent, 4(1), pp. 1-14. doi: 10.1080/23311975.2017.1309783.

[21] Kotler, P. and Armstrong, G. (2008) Principles of Marketing. 12th edn. Upper Saddle River, New Jerser: Pearson Prentice-Hall.

[22] Kumar, V., Rahman, Z., Kazmi, A. A. and Goyal, P. (2012) 'Evolution of Sustainability as Marketing Strategy: Beginning of New Era', Procedia - Social and Behavioral Sciences. Elsevier B.V., 37, pp. 482-489. doi: 10.1016/j.sbspro.2012.03.313.

[23] Lynn R. Kahle, Sharon E. Beatty, P. H. (1988) 'Problems with VALS in international marketing research : an example from an application of the empirical mirror technique', Advances in Consumer Research, 15, pp. 375-381.

[24] Maria Geiger, S., Fischer, D., Schrader, U. and Geiger, S. M. (2017) 'Measuring What Matters in Sust ainable Consum ption: An Integrative Framework for the Selection of Relevant Behaviors.', Sustainable Development, (May). doi: 10.1002/sd.1688/full.

[25] MHLG (2006) 'The study on national waste minimisation in Malaysia. M. O. H. A. L. GOVERNMENT. Malaysia Japan international cooperation agency. (2006 )’, I(July).

[26] Narang, R. (2011) 'Examining the role of various psychographic characteristics in apparel store selection: A study on Indian youth', Young Consumers, 12(2), pp. 133 144. doi: 10.1108/17473611111141597.

[27] National Solid Waste Management Department (2011) 'A Study on Plastic Management In Peninsular Malaysia', (December), p. 282. 
[28] Nations, U., Programme, E. and Unep (2010) United Nations Environment Programme, English. doi: 10.1016/0959-6526(93)90036-B.

[29] Noor, Z. (2016) 'Towards Sustainable Household Waste Management in Urban Areas: Determinants That Hindered The Recycling Activities in The City of Johor Bahru, Malaysia', Malaysia Sustainable Cities Program, Working Paper Series, pp. 1-20.

[30] Nora, Liza \& Minarti, N. S. (2016) 'The role of religiosity, lifestyle, attitude as determinant purchase intention', in The 2nd International Multidisciplinary Conference 2016, pp. 135-148.

[31] Novak, T. P. and MacEvoy, B. (1990) 'On Comparing Alternative Segmentation Schemes: The List of Values (LOV) and Values and Life Styles (VALS)', Journal of Consumer Research, 17(1), pp. 105-109. doi: 10.1086/208541.

[32] Periathamby, A., Hamid, F. S. and Khidzir, K. (2009) 'Evolution of solid waste management in Malaysia: Impacts and implications of the solid waste bill, 2007', Journal of Material Cycles and Waste Management, 11(2), pp. 96-103. doi: 10.1007/s10163-008-0231-3.

[33] Reisch, L. A., Cohen, M. J., Thøgersen, J. B. and Tukker, A. (2016) 'Frontiers in sustainable consumption research', Gaia, 25(4), pp. 234-240. doi: 10.14512/gaia.25.4.4.

[34] Ryden, L., Filho, W. L., Skubala, P. and Kronlid, D. (no date) 'Behaviour and the Environment: ethics, education and lifestyle', in Behaviour and the Environment, pp. 630-660.

[35] Samah, M. A. A., Manaf, L. A., Ahsan, A., Sulaiman, W. N. A., Agamuthu, P. and D’Silva, J. L. (2013) 'Household solid waste composition in Balakong City, Malaysia: Trend and management', Polish Journal of Environmental Studies, 22(6), pp. 18071816. doi: 10.1016/j.jenvman.2014.11.021.

[36] Sathish, S. and Rajamohan, a (2012) 'Consumer behaviour and lifestyle marketing', International Journal of Marketing, Financial Services \& Management Research, 1(10), pp. 152-166.

[37] Sjöberg, L. and Engelberg, E. (2005) 'Lifestyles, and risk perception consumer behavior', International Review of Sociology, 15(2), pp. 327-362. doi: 10.1080/03906700500159755.

[38] Vinson, D. E., Munson, J. M. and Nakanishi, M. (1977) 'An Investigation of the Rokeach Value Survey For Consumer Research Applications', Advances in Consumer Research, 4(1), pp. 247-252.

[39] Vranjanac, Z. and Spasic, D. (2017) 'Economic and environmental effects of collection and primary recycling of packaging waste from hygiene and cleaning products in Serbia', Serbian Journal of Management, 12(2), pp. 315-327. doi: 10.5937/sjm1211998.

[40] Winters, L. C. (1989) 'SRI Announces VALS 2', Marketing Research, (June), pp. 6769.

[41] WRAP (2013) 'Plastic packaging compostion 2011', p. 46.

[42] Yankelovich, D. and Meer, D. (2006) 'Rediscovering Market Segmentation Rediscovering Market Segmentation', Harvard Business Review, 84(2), pp. 122-131. doi: Article. 